instead of redesigning oil tankers or reexamining our energy-intensive and wasteful economy or making a serious effort to shift to renewable and ubiquitous energy sources.

That in the socialist countries, where there is no advertising, cigarette consumption is even higher than in the capitalist world, and that work is already in progress to produce genetically engineered microbes intended to provide a renewable energy source which would do away with oil tankers altogether, is apparently not known to Cavalieri. But for him the most ominous long-term hazard is the application of recombinant DNA techniques to the human genome. $\mathrm{He}$ admits that there is the possibility of performing "gene therapy" on a number of hereditary defects. But Cavalieri finds that it is not "a high priority line of research to be chosen in preference to other directions" and its benefits pale in camparison with the spectre of eugenics, which "received considerable support from industrialists like the Harrimans, Kelloggs and Carnegies". Though "its demise was aided by the repugnancy of emerging Nazism . . . with the development of new genetic techniques the eugenics movement in America could rise again".

To this it can be said, first, that whereas it is true that the project of improving the human "gene pool" by eugenic methods has fascinated many prominent geneticists, it is also a fact that despite the long-time availability of techniques (such as artificial insemination) for implementing eugenic goals by methods more humane than those practised in Nazi Germany, wide-scale eugenics has not come into use in any democratic society. So, there seems to be a firm (probably religiously rooted) resistance to eugenics, leaving its advocacy mainly to scientistic cranks. Second, and more importantly, it may be the case that any answer to "the classical question: who decides what is a defect?" could lead to procedures "clearly open to abuse". But, all the same, opposing on those grounds the use of diagnostic, prophylactic and corrective procedures in medical genetics reveals a lack of genuine empathy with and concern for people in the real world, since there are hereditary disorders that every person would judge to be defects with which no human being ought to be born. Thus Cavalieri's argument against genetic engineering from long-term hazards consists merely of general cant about Henry Ford, nuclear spills and the Nazis, and puts forward no specific prognosis that can be critically examined and discussed. Rather, just as does the argument from immediate biohazards, this argument, too, merely indicates a radical lack of faith in the honesty and wisdom of the leaders responsible for the management of our democratic society and of our scientific colleagues.

3. The potential benefits of moleculargenetic engineering are too small to offset the enormous risks. "The now familiar list of potential benefits that may accrue from recombinant DNA includes .... the production of insulin ... antibiotics ... vitamins and hormones. . . and ... food crops. . . . Do we need them?". Cavalieri answers "no". As for insulin, a "thoughtful approach to the problem of diabetes ... was given by Harvard's Professor Ruth Hubbard" who declared insulin to be a "technological gimmick". She counsels that we should rather try to find "the causes of diabetes, which are, as with all other diseases, heavily influenced by social and environmental factors"'. And as for antibiotics, vitamins and hormones, in the United States we have already 20,000 pharmaceutical products in medical use, when "the World Health Organization has indicated that only 210 drugs would be sufficient to fill world health needs". And as for food crops, "we must not let our understandable sympathy for the hungry people of the world lead us into mistaking the cause of the problem, which is not one of production or quality but of distribution and utilization. The world now produces enough grain to feed everyone adequately". That is to say, abundant food is available to feed the hungry, if only the nations with undernourished populations would organize better politically and economically so that they can buy food from the affluent countries that waste their food surpluses anyhow. So "no real need has yet been brought forward to justify the serious ecological hazards of introducing major disturbances into the complex balance of things" by recombinant DNA methodology.

It is not necessary here to enter into a dis- cussion of the merits of Cavalieri's claims. For even if these claims were just, the finitude of his list of potential benefits and his additional pronouncement that "we are no longer in an area when practical applications of scientific research are unforeseeable and the human consequences unknown" show a demagogic refusal to allow that what is sauce for the goose is also sauce for the gander. If it is the case that, as Cavalieri claims elsewhere, history teaches us that the long-term hazards of scientific and technological developments are always unforeseeable, he cannot in good faith allege that the time has come when all their benefits are foreseeable. Moreover, Cavalieri's competence to discuss, not ethics, but modern DNA research is put into question by his failure to mention the amazing advances that recombinant DNA techniques have brought to our understanding of the molecular organization of genetic structures in the past three or four years. An author of a book on recombinant DNA that appeared in 1981 who does not mention the discoveries of the fragmentation of eukaryotic genes and the mechanism of generating the diversity of antibody specificity, neither of which could have been made without the use of recombinant DNA methods, commands just about as little credence among biologists as one who, in the $1960 \mathrm{~s}$, would have failed to mention the discovery of the genetic code.

Gunther S. Stent is Chairman of the Department of Molecular Biology and Director of the Virus Laboratory at the University of California, Berkeley.

\title{
A haunted house of cards
}

\section{D.R. Newth}

A New Science of Life: The Hypothesis of Formative Causation. By Rupert Sheldrake. Pp.229. ISBN 0-85634-115-0. (Blond \& Briggs: 1981.) $£ 12.50$. To be published in the US in January 1982 by Tarcher, Los Angeles.

THE title of this book is misleadingly modest. The author is not content to propose only a new science of life, for he reassesses many features of the real world that have been revealed by natural science, and proposes that there exists a great conservative principle making itself felt as much, or more, by sub-atomic particles as in developing embryos or in the behaviour of human beings. The principle is that what happens, or has happened, can exert an influence that is without decrement in space or time upon future events of a similar kind. This influence acts to promote a repetition of what has gone before. The degree of similarity qualifying a living organism to respond to these persuasive messages appears to be conspecificity. Not all decisions or events, however, are susceptible to the principle of "formative causation".

The immediate recipient of the messages is a "morphogenetic field" which guides formal change in its associated "morphogenetic germ" until its prescriptions have been met and the "morphic unit" is finally co-extensive with the field. The morphogenetic field blends the experience of all previous similar morphic units by a process of "morphic resonance". Neither morphic resonance nor the obedience of the morphogenetic germ to the dictates of its morphogenetic field involve exchanges of matter or energy.

This, I understand it, is the burden of Dr Sheldrake's argument.

It is, of course, brave to expound in little more than 200 pages so revolutionary a denial of everything that empirical science has made seem probable. Nor should we deny some leniency to the holders of really way-out ideas. They lack the support of an established terminology, and the com- 
forting background of assumptions held in common with their readers. But they should at least try to be clear, at whatever cost to their credibility.

Dr Sheldrake writes as Mrs Bloom daydreamed, with no one theme rigorously explored before it sets off another which before resolution gives way to something else again. It would be unkind to suggest that this is a device for escaping from difficulties, but even readers who are wholly unsympathetic might welcome a clearer view of the author's position. For example, in discussing the limitations of morphic resonance he assumes that while past events can be effective now, future events cannot. While conceding that it is logically conceivable that they might be, he excludes the future on the ground of simplicity and remarks severely that "only if there were persuasive empirical evidence for a physical influence from future morphic events would it become necessary to take this possibility seriously". Apart from the ambiguity of introducing physical influences into a discussion of extraphysical phenomena, one is left wondering why the same severity is not applied to the past.

Indeed, Dr Sheldrake does believe that his ideas are capable of receiving support from experiment, but his proposals for experiments are curiously tentative and unsatisfactory. Thus

... if thousands of rats were trained to perform a new task in a laboratory in London, similar rats should learn to carry out the same task more quickly in laboratories everywhere else. If the speed of learning of rats in another laboratory, say in New York, were to be measured before and after the rats in London were trained, the rats tested on the second occasion should learn more quickly than those tested on the first.

Well, yes, but so they should without the London intervention, and any quantitative predictions in the operation of this hypothetical principle are so wholly arbitrary that the design of such experiments would be difficult indeed. Dr Sheldrake concedes this in his rather casual

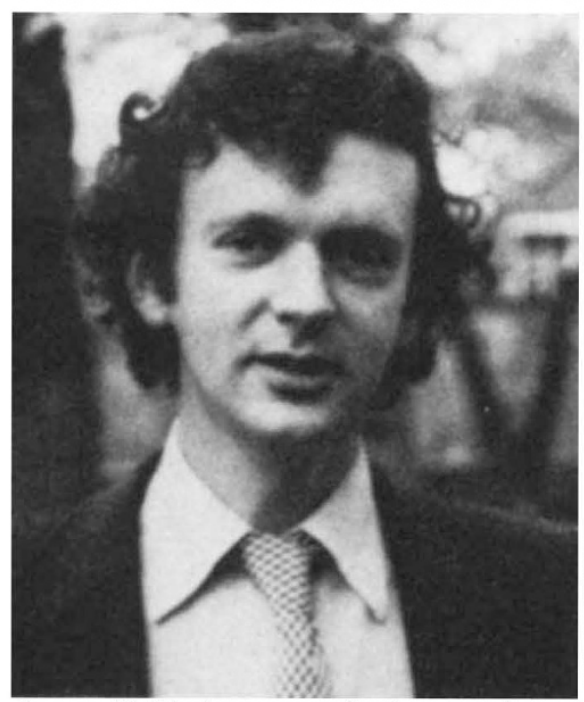

Rupert Sheldrake - contribution to a happy state of confusion? suggestions for a handful of investigations in each of which he describes a possible result supporting formative causation, but the opposite result is inconclusive. It would be a help if he could offer us predictions the failure of which would end the matter.

Anyone tempted to take formative causation or morphic resonance seriously should ask themselves why. A world haunted by messages from the past, some, like those from morphic units of extinct species, destined to vibrate eternally and in vain while seeking a morphic germ with which to resonate, may have a poetic appeal. Unfortunately it may also appeal to a perverse fear of scientific understanding. Dr Sheldrake explains early in the book

that while some outstanding biological problems are difficult, others are, in principle, insoluble - for example, those associated with evolution and with the origin of life. Neither, as it happens, is suitable for the operation of formative causation, since they are creative and unique rather than repetitive. But by the end of his exposition one reader had the distinct impression that intrinsic insolubility had its own attractions for him and that the hypothesis of formative causation was his contribution to a happy state of confusion.

D.R. Newth is Regius Professor of Zoology at the University of Glasgow.

\section{Selling newspapers and selling science}

\section{Eric Ashby}

Reflections on Science and the Media. By June Goodfield. Pp.128. ISBN 0-87168252-4. (American Association for the Advancement of Science: 1981.) $\$ 9$.

"JULES de Goncourt once wrote that ... the newspaper bore the same relationship to a book as a whore did to a decent woman". A verdict, as June Goodfield says, "too harsh by far"; but as a caricature of the way some of the mass media deal with science it has an uncomfortable relevance. A news item is a one-night affair unless it attracts enough readers or the TV ratings to justify a follow up. As soon as the issue no longer stimulates the reader or the viewer it is dropped. Never mind that the issue is important, still unresolved and ought to be kept before the public: out it goes to make room for something more newsworthy. Of course there are honourable exceptions to this generalization, but as a rule news keeps no better than fish; indeed less well than fish, for fish can be put in cold store and still eaten with relish. News that has been put in store is worthless.

This is one of the reasons for the mutual suspicion between scientists and journalists. They work on different timescales. The scientist who publishes halfbaked findings loses the respect of his peers. The journalist who fails to publish his findings promptly, however half-baked they are, loses his job. And on the journey from the laboratory to the news-stand the information may get horribly distorted. The interview between journalist and scientist may have lasted an hour; the journalist has to chip away the reservations and complexities so that he can fit the story into half a column; the sub-editor (the worst culprit of all) slices chunks out of the journalist's copy and adds a sensational headline which must often sicken the journalist as well as infuriate the scientist who in good faith has explained his work.
And the outcome: a wider alienation between science and the media.

This didn't matter in the days before the public became the patrons of science. It would not matter today if everyone read the New Scientist or the science correspondents in the quality newspapers, or even watched science programmes on the BBC. But they don't, and they pay taxes some of which support science. What should they be told about science?

In the United States the presentation of science on TV is much less satisfactory than it is in Britain, and science in the massmedia newspapers is no better reported than it is in Britain. The only science that is "sold" to the public is likely to be scandalous (for example the thalidomide affair) or open to ominous speculations (genetic engineering) or fashionable (pollution, in the 1970s). What is urgently needed is a much better public understanding of what science is about, how it is done and what consequences it has for society. These are difficult matters to put across and there's no money to reward those who try to do it.

It was, therefore, an excellent idea for the American Association for the Advancement of Science to commission an essay on science and the media, and a brilliant choice to offer the commission to June Goodfield, who already has an international reputation for her interpretation of science to the so-called lay reader. With first hand experience in the two professions of journalism and science and a sympathetic understanding of the constraints under which both these professions work, she has offered a clear and in places refreshingly provocative analysis of the "uneasy relationship" (as she calls it) between the two professions.

She rejects the view (still held, alas! by some scientists) that the great bingoplaying, football pools, top-of-the-pops majority don't need to be told about 